УДК 57, 573, 574

\title{
ВЛИЯНИЕ ТЕТРАМЕТИЛТИУРАМДИСУЛЬФИДА НА КОЛИЧЕСТВЕННОЕ СОДЕРЖАНИЕ МАЛОНОВОГО ДИАЛЬДЕГИДА В РОТОВОЙ ЖИДКОСТИ КРЫС
}

\author{
Ячменева Лилия Александровна \\ аспирант кафедры биологии, медицинской генетики и экологии, \\ ассистент кафедры ортопедической стоматологии \\ Королев Владимир Анатольевич \\ д.б.н., профессор, \\ зав. кафедрой биологии, медицинской генетики и экологии \\ Фелькер Елена Викторовна \\ к.м.н., доцент, \\ зав. кафедрой ортопедической стоматологии \\ Королев Иван Владимирович \\ ФГБОУ ВО «Курский государственный \\ медицинский университет» Минздрава России
}

Аннотация: Целью исследования было определение уровня малонового диальдегида в ротовой жидкости у крыс при пестицидной интоксикации тетраметилтиурамдисульфидом. В результате было установлено, что на 28 сутки концентрация малонового диальдегида увеличилась на $162 \%$. Анализ концентрации МДА на 7, 14, 21 сутки показали рост показателей на 72,54 \%, 94,11\%, 150\% соответственно. Результаты свидетельствуют о повышении процессов перекисного окисления липидов в ротовой жидкости с увеличением сроков пестицидной интоксикации.

Ключевые слова: тетраметилтиурамдисульфид, антиоксидантная система, оксидативный стресс, перекисное окисление липидов, малоновый диальдегид 


\title{
EFFECT OF TETRAMETHYLTHIURAM DISULFIDE ON THE QUANTITATIVE CONTENT OF MALONDIALDEHYDE IN RAT ORAL FLUID
}

\author{
Yachmeneva Liliya Aleksandrovna \\ Korolev Vladimir Anatolyevich \\ Felker Elena Viktorovna \\ Korolev Ivan Vladimirovich
}

\begin{abstract}
The aim of the study was to determine the level of malondialdehyde in the oral fluid during pesticide intoxication with tetramethylthiuramdisulfide. As a result, it was found that on day 28 , the concentration of malondialdehyde increased by $162 \%$. Analysis of MDA concentrations on days 7, 14, and 21 showed an increase in indicators by $72.54 \%, 94.11 \%$, and $150 \%$, respectively. The results indicate an increase in the processes of lipid peroxidation in the oral fluid with an increase in the duration of pesticide intoxication.
\end{abstract}

Key words: tetramethylthiuram disulfide, antioxidant system, oxidative stress, lipid peroxidation, malondialdehyde

В современном мире перед сельским хозяйством стоит проблема увеличения урожайности агрокультур. Ежегодно происходит значительная потеря урожая из-за возбудителей грибковых заболеваний культур, для борьбы с которыми в аграрном комплексе активно используют фунгицидные ядохимикаты. К таким пестицидам относится тетраметилтиурамдисульфид (ТМТД). ТМТД является фунгицидом контактного действия, и может длительно сохраняться в продуктах первичной переработки культур. ТМДТ токсически воздействует на живые организмы, вызывая патологические, чаще всего необратимые, процессы. При действии ТМДТ возникает нарушение работы антиоксидантной системы и как следствие формируется оксидативный стресс $[2,4]$.

Оксидативный стресс возникает в условиях патологии или интоксикации, и характеризуется нарушением баланса между прооксидантными и антиоксидантными защитными механизмами организма [6]. Ускорение процессов перекисного окисления липидов (ПОЛ) является причиной дестабилизации мембран и развития патологических процессов. Присутствие продуктов ПОЛ обуславливают изменение в фосфолипидах и фосфолипидном 
комплексе, что может привести к нарушениям целостности строения клеток, а далее всего организма. Жирные кислоты в локациях соединения перекисных радикалов разделяются на элементы, по краям которых находятся альдегидные группы, обладающие высокой реакционной способностью. Когда разрыв происходит с двух сторон, образуется малоновый диальдегид (МДА). МДА является эндогенным альдегидом, который образуется в ходе метаболизма арахидоновой и полиненасыщенных жирных кислот и в дальнейшем окисляется до диоксида углерода. По цепочке МДА начинает реагировать с $\mathrm{SH}-и$ группами и CH3- группами белков и подавляет ферменты гидроксилазу, цитохромоксидазу и др. Интенсивность перекисного окисления липидов оценивают по содержанию малонового диальдегида. МДА является одним из показателей оксидативного стресса, его анализ позволяет в ротовой жидкости в условиях пестицидных нагрузок оценить степень и интенсивность работы антиоксидантных ферментов [3].

Целью исследования было определить уровень МДА в ротовой жидкости при пестицидной интоксикации

Материалы и методы исследования. Исследование было проведено на 160 крысах линии Вистар с массой тела 200-220 граммов. При этом эксперименте животные были разделены на 2 группы. 1 группа - здоровые, интактные крысы, которые являются биологическим контролем. 2 группа получала ТМДТ вместе с пищей в дозе 0,0016 мг, что является 1/50 LD50, в течение 28 дней. Оценку показателей проводили на 7, 14, 21 и 28 сутки интоксикации.

Материалом исследования явилась ротовая жидкость, которая была получена путем забора с помощью микропипетки в чистую пробирку нестимулированной ротовой жидкости. Центрифугировали при 1500 оборотах 20 минут. Ротовую жидкость забирали и помещали в эппендорф, V=1,5 мл. Хранили при температуре $-25^{\circ} \mathrm{C}$ в холодильнике [1].

Содержание малонового диальдегида оценивали спектрофотометрически. Результаты выразили в мкмоль/л в ротовой жидкости [5].

Результаты исследования и их обсуждение.

Полученные данные представлены в таблице № 1. 


\section{Таблица 1}

\section{Показатели уровня малонового диальдегида (МДА) в ротовой жидкости} при пестицидной нагрузке в мкмоль/л.

\begin{tabular}{|l|l|l|c|c|c|}
\hline $\begin{array}{l}\text { Показатель, } \\
\text { усл. ед }\end{array}$ & \multicolumn{1}{c|}{$\begin{array}{c}\text { Контроль } \\
\text { (интактные) }\end{array}$} & $\begin{array}{c}\text { ТМДТ } \\
7 \text { сут. }\end{array}$ & $\begin{array}{c}\text { ТМДТ } \\
14 \text { сут. }\end{array}$ & $\begin{array}{c}\text { ТМДТ } \\
21 \text { сут. }\end{array}$ & $\begin{array}{c}\text { ТМДТ } \\
28 \text { сут. }\end{array}$ \\
\hline $\begin{array}{l}\text { МДА, } \\
\text { мкмоль/л }\end{array}$ & $1,02 \pm 0,12$ & $1,76 \pm 0,17 * * *$ & $1,98 \pm 0,14 * * *$ & $2,55 \pm 0,18 * * *$ & $2,68 \pm 0,23 * * *$ \\
\hline
\end{tabular}

Примечание: * - p<0,05 по сравнению с контрольной группой, ** - p<0,01 по сравнению $\mathrm{c}$ контрольной группой, *** - $<<0,001$ по сравнению $\mathrm{c}$ контрольной группой.

Оценка результатов количественного содержания МДА в ротовой жидкости при хронической пестицидной интоксикации показала увеличение показателя. Максимальная концентрация МДА была выявлена на 28 сутки интоксикации, что превышает контрольные значения в 2,5 раза, на $162 \%$. Полученные данные свидетельствуют об интенсивности процессов перекисного окисления липидов в ротовой жидкости при пестицидной интоксикации и накопление малонового диальдегида. Анализ концентрации МДА на 7, 14, 21 сутки показали рост показателей на 72,54 \%, 94,11\%, 150\% соответственно. Данные результаты свидетельствуют о повышении процессов перекисного окисления липидов в ротовой жидкости с увеличением сроков пестицидной интоксикации.

Выводы. Хроническая интоксикация тетраметилтиурамдисульфидом вызывает значительное увеличение показателей малонового диальдегида в ротовой жидкости крыс, что говорит о проявлении оксидативного стресса и нарушении баланса между прооксидантными и антиоксидантными защитными механизмами. Для коррекции прооксидантно-антиоксидантного баланса необходима разработка методов антиоксидантной терапии.

\section{Список литературы}

1. Агейченко, А.В. Состояние микробиоценоза толстого кишечника, липидного состава клеточных мембран и антиоксидантного статуса животных при экспериментальном дисбиозе: Дис. канд. мед. наук: 03.02.03/ А.В. Агейченко; КГМУ. - Курск, 2016. -115с

2. Агроэкология / под общ. ред. В.А. Черникова. - М: Колос, 2000. - 536 с. 
3. Владимиров Ю.А. Роль нарушений свойств липидного слоя мембран в развитиии патологических процессов. //Патол. физиология и эксперим. терапия.- 1989.-№ 4. - С. 7-19.

4. Влияние острой или хронической интоксикации банколом на состояние процессов перекисного окисления липидов и активность антиоксидантных ферментов / Ю.Д. Ляшев, В.А. Королев, Н.Е. Кирищева, И.В. Грибач // Патологическая физиология и экспериментальная терапия. -2016 . - № 2. C. 69-73.

5. Гаврилов В.Б., 1983; Кушманова О.Д., 1983; Строев В.А., 1986; Дерюгина А.В., 2010; Некрасов Э. В., 20122.

6. Pushkina T.A., Tokayev E.S., Popova T.S., Borodina E.N. Superoxide dismutase as a component of antioxidant therapy: current state of the issue and prospects. A literature review. Sklifosovsky Journal of Emergency Medical Care. 2016;(4):42-47. (In Russian). 